\title{
ANALISIS PENGARUH INVESTASI, TENAGA KERJA DAN TINGKAT PENDIDIKAN TERHADAP PERTUMBUHAN EKONOMI DAN DAMPAKNYA TERHADAP KEMISKINAN DI PROPINSI SULAWESI UTARA
}

\author{
Risky Pratama, Prof. Dr. Paulus Kindangen, Een N. Walewangko \\ Ekonomi Pembangunan - Fakultas Ekonomi dan Bisnis \\ Universitas Sam ratulangi
}

\begin{abstract}
ABSTRAK
Penelitian ini bertujuan untuk menganalisis pengaruh jumlah investasi (PMDN dan PMA), jumlah tenaga kerja dan tingkat pendidikan, terhadap pertumbuhan ekonomi dan dampaknya terhadap kemiskinan di Sulawesi Utara. Adapun data yang digunakan penulis dalam penelitian ini adalah data sekunder berjenis time series sejak tahun 2003 hingga tahun 2015 yang diperoleh dari Badan Pusat Statistik Sulawesi Utara.

Metode yang digunakan dalam penelitian ini adalah Analisis Path. Hasil analisis menunjukkan investasi memberikan pengaruh yang signifikan terhadap pertumbuhan ekonomi begitu juga dengan tenaga kerja yang memberikan pengaruh yang signifikan terhadap pertumbuhan ekonomi, Tingkat Pendidikan juga memberikan pengaruh yang signifikan terhadap pertumbuhan ekonomi. Sedangkan investasi memberikan pengaruh tidak langsung yang signifikan terhadap kemiskinan melalui pertumbuhan ekonomi di Sulawesi Utara, akan tetapi tenaga kerja secara tidak langsung belum bisa memberikan pengaruh yang signifikan terhadap kemiskinan melalui pertumbuhan ekonomi. Tingkat Pendidikan memberikan pengaruh yang signifikan terhadap kemiskinan. Pertumbuhan ekonomi memberikan pengaruh yang signifikan terhadap kemiskinan di Sulawesi Utara.
\end{abstract}

Kata Kunci : investasi, tenaga kerja, tingkat pendidikan, pertumbuhan ekonomi, kemiskinan, Analisis Path.

\begin{abstract}
The objective of this research is to analyze the influence of investment (PMDN and PMA), the number of workers and the level of education, on economic growth and its impact on poverty in North Sulawesi. The data used by the authors in this study is the secondary data type time series from 2003 to 2015 obtained from the Central Bureau of Statistics of North Sulawesi

The method used in this study is Path Analysis. The analysis showed that the investment has a significant effect on economic growth as well as the labor force which gives significant effect to economic growth, the level of education also gives a significant influence to economic growth. While investment provides a significant indirect effect on poverty through economic growth in North Sulawesi, but indirect labor has not been able to give a significant effect on poverty, through economic growth. Education has a significant effect on poverty. Economic growth has a significant effect on poverty in North Sulawesi.
\end{abstract}

Keywords: Investments, Labor, Education Level, Economic growth, Poverty, Path Analysis. 


\section{PENDAHULUAN}

\section{Latar Belakang Masalah}

Kemiskinan merupakan salah satu masalah utama yang dihadapi hampir seluruh Negara di dunia, terbukti PBB telah menetapkan Substainable Development Goals (SDGs), dimana terdapat 17 agenda penting yang harus dicapai pada tahun 2030 Salah satu tujuannya adalah pemberantasan kemiskinan, pengangguran, peningkatan pendidikan dan pembangunan global, dimana pada tahun 2030 proporsi penduduk yang hidup di bawah garis kemiskinan harus dikurangi hingga 50 persen dari kondisi capaian Millenium Development Goals (MDGs). Dengan kata lain permasalahan kemiskinan menjadi "Tulang punggung" di dalam agenda pembangunan berkelanjutan (Ah Maftuchan, 2015).

Kemiskinan muncul karena adanya ketidaksamaan pola kepemilikan sumber daya yang menimbulkan ketimpangan pendapatan, penduduk miskin hanya memiliki sumber daya yang terbatas dengan kualitas yang rendah, selain itu kemiskinan muncul karena perbedaan kualitas sumber daya manusia, dimana kualitas sumber daya manusia yang rendah maka produktifitas yang dihasilkan juga rendah, kemiskinan muncul karena adanya perbedaan akses modal (Kuncoro,2000). Dalam agenda mendukung mengurangi tingkat kemiskinan dan peningkatan kesejahteraan masyarakat pemerintah telah menerbitkan peraturan presiden Nomor 15 tahun 2010, tentang percepatan penanggulangan kemiskinan.

Presentase Penduduk Miskin Di Indonesia

( Kemiskinan Relative Dan Kemiskinan Absolut)

Tahun 2009-2014

\begin{tabular}{|c|c|c|c|c|c|c|c|}
\hline & $\mathbf{2 0 0 9}$ & $\mathbf{2 0 1 0}$ & $\mathbf{2 0 1 1}$ & $\mathbf{2 0 1 2}$ & $\mathbf{2 0 1 3}$ & $\mathbf{2 0 1 4}$ & $\mathbf{2 0 1 5}$ \\
\hline $\begin{array}{c}\text { Kemiskinan } \\
\text { Relatif (\% dari } \\
\text { nonulasi) }\end{array}$ & 14.2 & 13.3 & 12.5 & 11.7 & 11.5 & 11 & 11.2 \\
\hline $\begin{array}{c}\text { Kemiskinan } \\
\text { Absolut (dalam } \\
\text { intaan) }\end{array}$ & 33 & 31 & 30 & 29 & 29 & 28 & 29 \\
\hline
\end{tabular}

Sumber : Badan Pusat Statistik Sulawesi Utara 2015.

Tabel di atas menunjukkan menurunya angka kemiskinan nasional secara relatif dimana pada tahun 2009 berada pada angka 14,2\% kemudian terus mengalami penurunan hingga menjadi 11,2\% pada tahun 2015 .

Kuznets juga mendefenisikan pertumbuhan ekonomi sebagai kenaikan jangka panjang dalam kemampuan suatu negara untuk menyediakan semakin banyak barang kepada penduduknya (Jhinghan, 2010). Namun, dalam kenyataannya kondisi perekonomian pada umumnya mengalami gelombang pasang surut. Hal ini juga untuk 
mengurangi kemiskinan yang terjadi di Provinsi Sulawesi Utara.

Tingkat Kemiskinan Dan Pertumbuhan Ekonomi

Propinsi Sulawesi Utara Tahun 2009 - 2015

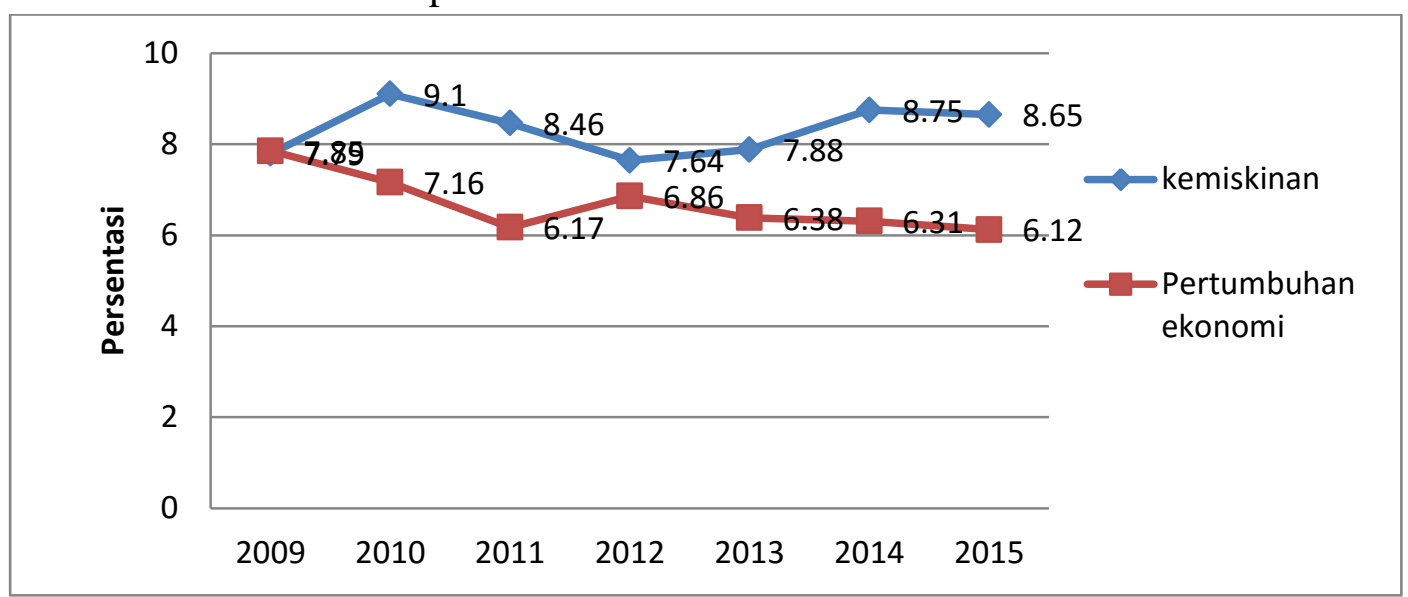

Sumber : Data Olahan, BPS 2016

Dilihat dari kinerja perekonomian Sulawesi Utara tahun 2009 - 2015 mengalami penurunan (Diagram 1). Pada tahun 2010 pertumbuhan ekonomi turun menjadi 7.16 persen dan memberikan dampak terhadap kemiskinan yang meningkat menjadi 9.1. Kemudian pertumbuhan ekonomi kembali mengalami penurunan pada tahun 2011 menjadi 6.17 tetapi kemiskinan menurun menjadi 8.46 persen. Di tahun 2012 pertumbuhan ekonomi meningkat menjadi 6.86 persen dari tahun sebelumnya dan memberikan dampak positif terhadap kemiskinan yang menurun menjadi 7.64 persen. Pada tahun 2013-2014 laju pertumbuhan ekonomi menurun dari 6,38 persen menjadi 6,31 persen. Ini memberikan dampak terhadap kemiskinan Sulawesi Utara yang naik dari 7.88 persen pada tahun 2013 menjadi 8.75 pada tahun 2014. Pertumbuhan ekonomi kembali mengalami penurunan hingga 6,12 persen pada tahun 2015. Sementara itu kemiskinan mengalami penurunan pada tahun 2015 menjadi 8.65 persen.

\section{Rumusan Masalah}

Berdasarkan latar belakang masalah di atas, maka permasalahan dalam penelitian ini disusun sebagai berikut:

1. Bagaimana pengaruh investasi, tenaga kerja dan tingkat pendidikan terhadap pertumbuhan ekonomi di Provinsi Sulawesi Utara selama tahun 2003-2015 secara parsial.

2. Bagaimana pengaruh investasi, tenaga kerja dan tingkat pendidikan terhadap kemiskinan di Provinsi Sulawesi Utara selama tahun 2003-2015 secara parsial.

3. Bagaimana pengaruh tingkat pertumbuhan ekonomi terhadap kemiskinan di Sulawesi Utara selama tahun 2003-2015.

\section{Tujuan Penelitian}

Tujuan dari penelitian ini adalah sebagai berikut. 
1. Menganalisa pengaruh jumlah investasi, tenaga kerja dan tingkat pendidikan terhadap pertumbuhan ekonomi di Provinsi Sulawesi Utara.

2. Menganalisa pengaruh jumlah investasi, tenaga kerja dan tingkat pendidikan terhadap kemiskinan di Provinsi Sulawesi Utara.

3. Menganalisa pengaruh pertumbuhan ekonomi terhadap kemiskinan di Provinsi Sulawesi Utara.

\section{Manfaat Penelitian}

Sementara itu, penelitian ini diharapkan dapat memberikan manfaat bagi beberapa pihak :

1. Manfaat Akademisi

Hasil penelitian dihapkan mampu menambah pengetahuan dalam bidang ekonomi perencanaan, wawasan terhadap pembangunan ekonomi masa depan dan sebagai bahan referensi bagi penelitian selanjutnya yang nantinya ingin mengambil tema tentang pertumbuhan ekonomi dan kemiskinan.

2. Bagi Pemerintah

Menjadi bahan masukan dan informasi bagi pemerintah dalam pengembilan keputusan dalam berinvestasi, ketenaga kerjaan dan pendidikan untuk menunjang pertumbuhan ekonomi dan penanggulangan kemiskinan dalam memberikan trend positif kepada pemerintah. Selanjutnya sebagai tolak ukur seberapa penting variable yang diujikan ini berpengaruh terhadap undang undang yang ada sebagai dasar patokan pemerintah sekarang.

3. Bagi Peneliti

Sebagai pembading terhadap teori - teori yang ada dari terdahulu hingga sekarang sesuai dengan mata kuliah yang telah dipelajari dan bahan informasi selanjutnya yang memberikan referensi baru dalam pemikiran yang akan datang.

\section{TINJAUAN PUSTAKA}

\section{Landasan Teori}

\section{Kemiskinan}

Istilah kemiskinan sangat mudah diucapkan tetapi tidak gampang untuk menentukan yang miskin itu yang seperti apa, siapa yang tergolong miskin, dan seterusnya (Sumedi, 2004). Kemiskinan telah mengalami perluasan, seiring dengan berkembangnya factor penyebab kemiskinan itu sendiri. Kemiskinan tidak lagi hanya dianggap sebagai dimensi ekonomi, tapi telah meluas ke dimensi lainnya. Kemiskinan dapat dilihat dari berbagai segi, baik dari pendapatan, pendidikan, kesehatan, ketenagakerjaan, laju pertumbuhan ekonomi,investasi, inflasi, ketahanan pangan, pembangunan infrastruktur sosial ekonomi wilayah (PISEW), tenaga kerja, perkembangan usaha ekonomi kerakyatan, ketimpangan struktur usaha, ketidakberdayaan, kesejahteraan sosial, ketimpangan gender, kesenjangan antar golongan dan wilayah, pembangunan sumber daya manusia. 


\section{Definisi Kemiskinan}

Menurut Bank Dunia, kemiskinan merupakan ketidakmampuan seseorang untuk memperoleh standar hidup yang minimal atau kemiskinan dapat juga diartikan mengenai keadaan melarat dan ketidakberuntungan atau suatu keadaan minus (deprivation). Kemiskinan juga berkaitan dengan rendahnya tingkat pendapatan dan kepemilikan harta, kelemahan fisik, isolasi, kerentanaan dan ketidakberdayaan (Chambers, 1987).

Pada dasarnya definisi kemiskinan dapat dilihat dari dua sisi, yaitu;

a. Kemiskinan Absolut

Kemiskinan yang dikaitkan dengan perkiraan tingkat pendapatan dan kebutuhan yang hanya dibatasi pada kebutuhan pokok atau kebutuhan dasar minimum yang memungkinkan seseorang untuk hidup secara layak. Dengan demikian kemiskinan diukur dengan membandingkan tingkat pendapatan orang dengan tingkat pendapatan yang dibutuhkan untuk memperoleh kebutuhan dasarnya yakni makanan, pakaian dan perumahan agar dapat menjamin kelangsungan hidupnya.

\section{b. Kemiskinan Relatif}

Kemiskinan dilihat dari aspek ketimpangan sosial, karena ada orang yang sudah dapat memenuhi kebutuhan dasar minimumnya tetapi masih jauh lebih rendah dibanding masyarakat sekitarnya (lingkungannya). Semakin besar ketimpangan antara tingkat penghidupan golongan atas dan golongan bawah maka akan semakin besar pula jumlah penduduk yang dapat dikategorikan miskin, sehingga kemiskinan relatif erat hubungannya dengan masalah distribusi pendapatan. Menurut Todaro dan Smith (2011) menyatakan bahwa variasi kemiskinan dinegara berkembang disebabkan oleh beberapa faktor, yaitu: (1) perbedaan geografis, jumlah penduduk dan tingkat pendapatan, (2) perbedaan sejarah, sebagian dijajah oleh negara yang berlainan, (3) perbedaan kekayaan sumber daya alam dan kualitas sumber daya manusianya, (4) perbedaan peranan sektor swasta dan negara, (5) perbedaan struktur industri, (6) perbedaan derajat ketergantungan pada kekuatan ekonomi dan politik negara lain dan (7) perbedaan pembagian kekuasaan, struktur politik dan kelembagaan dalam negeri.

\section{Mengukur Kemiskinan}

Untuk mengukur kemiskinan, Indonesia melalui BPS menggunakan pendekatan kebutuhan dasar (basic needs) yang dapat diukur dengan angka atau hitungan Indeks Perkepala (Head Count Index), yakni jumlah dan persentase penduduk miskin yang berada di bawah garis kemiskinan.

Prinsip - prinsip untuk mengukur kemiskinan, yakni: anonimitas, independensi, maksudnya ukuran cakupan kemiskinan tidak boleh tergantung pada siapa yang miskin 
atau pada apakah negara tersebut mempunyai jumlah penduduk yang banyak atau sedikit

Dua indeks kemiskinan yang sangat sering digunakan karena memenuhi empat kriteria tersebut adalah Indeks Send dan Indeks Foster Greer Thorbecke (FGT) (Palpa).

\section{Faktor-Faktor Penyebab Kemiskinan}

Kemiskinan banyak dihubungkan dengan:

1. Penyebab individual, atau patologis, yang melihat kemiskinan sebagai akibat dari perilaku, pilihan, atau kemampuan dari si miskin.

2. Penyebab keluarga, yang menghubungkan kemiskinan dengan pendidikan keluarga.

3. Penyebab sub - budaya (subcultural), yang menghubungkan kemiskinan dengan kehidupan sehari - hari, dipelajari atau dijalankan dalam lingkungan sekitar.

4. Penyebab agensi, yang melihat kemiskinan sebagai akibat dari aksi orang lain, termasuk perang, pemerintah, dan ekonomi.

5. Penyebab struktural, yang memberikan alasan bahwa kemiskinan merupakan hasil dari struktur sosial.

\section{Pembangunan Ekonomi}

Pembangunan ekonomi adalah kegiatan - kegiatan yang dilakukan suatu negara untuk mengembangkan kegiatan ekonomi dan taraf hidup masyarakatnya. Pembangunan ekonomi juga bisa didefinisikan sebagai suatu proses yang menyebabkan kenaikan pendapatan riil per kapita penduduk suatu negara dalam jangka panjang disertai oleh perbaikan sistem kelembagaan (Arsyad, 2004).

\section{Pertumbuhan Ekonomi}

Menurut Kuznets (dalam Todaro, 2006), pertumbuhan ekonomi adalah kenaikan kapasitas dalam jangka panjang dari negara yang bersangkutan untuk menyediakan berbagai barang ekonomi kepada penduduknya. Kenaikan kapasitas itu sendiri ditentukan atau dimungkinkan oleh adanya kemajuan atau penyesuaianpenyesuaian teknologi, institusional (kelembagaan) dan ideologis terhadap berbagai tuntutan yang ada. Kuznets juga mengemukakan bahwa ada setidaknya enam karakteristik atau ciri proses pertumbuhan ekonomi yang ditemui di hampir semua negara yang sekarang telah menjadi negara maju (developed countries) atau wilayah maju apabila berbicara dalam konteks ekonomi regional. Enam karakteristik proses pertumbuhan ekonomi menurut Kuznets tersebut antara lain :

1. Tingkat pertumbuhan output per kapita dan pertumbuhan penduduk yang tinggi.

2. Tingkat kenaikan total produktivitas faktor yang tinggi.

3. Tingkat transformasi struktural ekonomi yang tinggi.

4. Tingkat transformasi sosial dan ideologi yang tinggi. 
5. Adanya kecenderungan negara-negara yang mulai atau yang sudah maju perekonomiannya untuk berusaha menambah bagian - bagian dunia lainnya sebagai daerah pemasaran dan sumber bahan baku yang baru.

Terbatasnya penyebaran pertumbuhan ekonomi yang hanya mencapai sekitar sepertiga bagian penduduk yang ada.

\section{Investasi}

Investasi dapat diartikan sebagai pengeluaran atau perbelanjaan penanam penanam modal atau perusahaan untuk membeli barang-barang modal dan perlengkapan - perlengkapan produksi untuk menambah kemampuan memproduksi barang-barang dan jasa - jasa yang tersedia dalam perekonomian. Investasi tidak hanya untuk memaksimalkan output, tetapi untuk menentukan distribusi tenaga kerja dan distribusi pendapatan, pertumbuhan dan kualitas penduduk serta teknologi (Sukirno, 2005).

\section{Tenaga Kerja}

Menurut Badan Pusat Statistik (BPS), tenaga kerja adalah setiap orang yang mampu melakukan pekerjaan guna menghasilkan barang dan jasa baik untuk memenuhi kebutuhan sendiri maupun untuk masyarakat. Batas usia kerja yang dianut oleh Indonesia adalah minimum 10 tahun, tanpa batas umur maksimum. Jadi setiap orang atau penduduk yang sudah berusia 10 tahun keatas tergolong tenaga kerja.

\section{Tingkat Pendidikan}

Modal manusia adalah pengetahuan dan kemampuan yang diperoleh melalui pendidikan, mulai dari program untuk anak-anak sampai dengan pelatihan dalam pekerjaan (on the job training) untuk para pekerja dewasa (Mankiw, 2003). Meningkatkan level modal manusia dibutuhkan investasi dalam bentuk guru, perpustakaan dan waktu belajar.

\section{Kerangka Konseptual}

\section{Gambar 1}

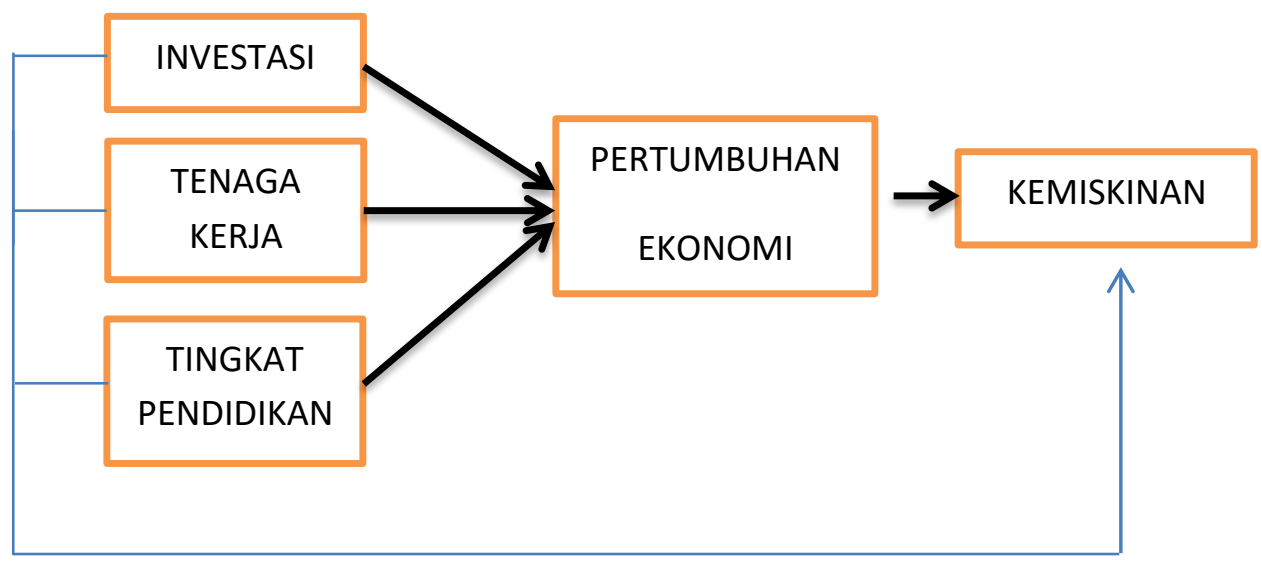




\section{Hipotesis}

Hipotesis adalah suatu pernyataan yang dikemukakan dan masih lemah kebenarannya. Hipotesis juga dipandang sebagai konklusi yang sifatnya sementara. Sesuai dengan kerangka penelitian di atas, maka hipotesis dalam penelitian ini diformulasikan sebagai berikut, diduga :

1. Investasi, Tenaga Kerja, dan Tingkat Pendidikan mempunyai pengaruh yang positif dan signifikan terhadap pertumbuhan ekonomi di Provinsi Sulawesi Utara.

2. Investasi, Tenaga Kerja, dan Tingkat Pendidikan mempunyai pengaruh tidak langsung yang negatif dan signifikan terhadap kemiskinan di Provinsi Sulawesi Utara.

Pertumbuhan ekonomi mempunyai pengaruh yang negatif dan signifikan terhadap Kemiskinan di Provinsi Sulawesi Utara.

\section{METODE PENELITIAN}

\section{Jenis dan Sumber Data}

Data yang digunakan dalam penelitian ini merupakan data sekunder (time series), yaitu data yang diperoleh berdasarkan informasi yang telah disusun dan dipublikasikan oleh instansi tertentu, antara lain berasal dari Badan Pusat Statistik (BPS) Propinsi Sulawesi Utara.

\section{Definisi Operasional}

Untuk memberikan pemahaman terhadap variabel dependen maupun independen dalam penelitian ini, maka diperlukan definisi operasional yakni:

1. Investasi

Investasi yang digunakan dalam penelitian ini adalah investasi yang berasal dari penjumlahan Penanaman Modal Asing (PMA) dan Penanaman Modal Dalam Negeri (PMDN). Satuan dari variabel investasi ini adalah satuan mata uang indonesia atau biasa disebut Rupiah (Rp).

\section{Tenaga Kerja}

Jumlah tenaga kerja yang berada di suawesi utara pada satu periode tertentu, misalnya 1 tahun dan dinyatakan dalam satuan orang.

3. Tingkat Pendidikan

Satuan dari variabel penduduk yang berpendidikan adalah orang atau jiwa. Penduduk yang berpendidikan dipergunakan penduduk yang tingkat pendidikannya mulai dari SMA ke atas.

4. Pertumbuhan Ekonomi

Pertumbuhan ekonomi adalah perubahan relatif nilai riil Produk Domestik Bruto (PDRB) di Propinsi Sulawesi Utara atas dasar harga konstan tahun 2000 dan dinyatakan dalam satuan persen.

\section{Kemiskinan}


Kemiskinan adalah jumlah penduduk miskin yang ada di Provinsi Sulawesi Utara pada 1 periode tertentu, 1 tahun dan dinyatakan dalam satuan orang.

\section{Metode Analisis Data}

Penelitian ini adalah penelitian kuantitatif menggunakan data sekunder rentang waktu antara tahun 2003-2015. Data merupakan segala keterangan atau informasi mengenai hal-hal yang berkaitan dengan tujuan penelitian. Data sekunder digunakan karena penelitian yang dilakukan meliputi objek yang bersifat makro dan mudah didapat. Data tersebut diolah kembali sesuai dengan kebutuhan model yang digunakan. Sumber data berasal dari berbagai sumber, antara lain Badan Pusat Statistik Propinsi Sulawesi utara dan jurnal-jurnal ilmiah serta literatur-literatur lain yang be rkaitan dengan topik penelitian ini. Selain itu, penulis juga melakukan studi literatur untuk mendapatkan teori yang mendukung penelitian. Referensi studi kepustakaan diperoleh melalui jurnal ilmiah dan perpustakaan FE Universitas Sam Ratulangi Manado. Untuk menghindari adanya perbedaan penafsiran, maka di bawah ini akan dijelaskan mengenai metode analisis dan definisi operasionalnya.

\section{Analisis Path}

Adapun metode analisis yang akan penulis gunakan adalah metode analisis jalur / Path Analysis. Dengan demikian model persamaan structural untuk analisis jalur tersebut dapat dirumuskan sebagai berikut :

$$
\begin{array}{ll}
\text { Model struktural I } & \mathrm{Y}_{1}=\alpha \mathrm{o}+\alpha_{1} \operatorname{Ln} \mathrm{X}_{1}+\alpha_{2} \operatorname{Ln} \mathrm{X}_{2}+\alpha_{3} \operatorname{Ln} \mathrm{X}_{3}+\mathrm{e} \\
\text { Model struktural II } & \mathrm{Y}_{2}=\beta \mathrm{o}+\beta_{1} \operatorname{Ln} \mathrm{X}_{1}+\beta_{2} \operatorname{Ln} \mathrm{X}_{2}+\beta_{3} \operatorname{Ln} \mathrm{X}_{3}+\beta_{4} \operatorname{Ln} \mathrm{Y}_{1}+\mathrm{e}
\end{array}
$$

Dimana :

$$
\begin{aligned}
& \mathrm{Y}_{1}=\text { Pertumbuhan Ekonomi } \\
& \mathrm{Y}_{2}=\text { Kemiskinan } \\
& \mathrm{X}_{1}=\text { Investasi } \\
& \mathrm{X}_{2}=\text { Tenaga Kerja } \\
& \mathrm{X}_{3}=\text { Tingkat Pendidikan } \\
& \mathrm{e}=\text { Error term }
\end{aligned}
$$

\section{HASIL PENELITIAN DAN PEMBAHASAN}

\section{Uji Asumsi Klasik}

Sebelum melakukan analisis data maka data diuji apakah telah memenuhi syarat - syarat yaitu lolos dari asumsi klasik. Syarat - syarat yang harus dipenuhi adalah data tersebut harus terdistribusikan secara normal, tidak mengandung multikolonialitas dan heterokedastisitas.

\section{a. Uji Normalitas Data}

Uji normalitas data dapat dilihat dengan menggunakan metode Kolmogorov-Smirnov test. Hasilnya adalah sebagai berikut : 


\section{Uji Normalitas Data}

One-Sample Kolmogorov-Smirnov Test

\begin{tabular}{|ll|l|}
\hline & & $\begin{array}{l}\text { Unstandardize } \\
\text { d Residual }\end{array}$ \\
\hline $\mathrm{N}$ & & 13 \\
Normal Parameters & $\mathrm{a}, \mathrm{b}$ & .0000000 \\
& Sean & .02961645 \\
Most Extreme Differences & Absolute & .152 \\
& Positive & .152 \\
& Negative & -.140 \\
Kolmogorov-Smirnov $\mathrm{Z}$ & & .547 \\
Asymp. Sig. (2-tailed) & & .925 \\
\hline
\end{tabular}

a. Test distribution is Normal.

b. Calculated from data.

Berdasarkan tabel diatas, diketahui bahwa nilai signifikansi sebesar 0.925 lebih besar dari 0.05, sehingga dapat disimpulkan bahwa data yang kita uji terdistribusi normal.

\section{b. Uji Multikolinearitas}

Hasil uji multikolinearitas dengan metode VIF dan Tolerance menunjukan hasil sebagaimana terdapat pada tabel sebagai berikut:

\section{Uji Multikolinearitas}

\begin{tabular}{|l|l|l|}
\hline \multirow{2}{*}{ Variabel } & \multicolumn{2}{|l|}{ Collinearity Statistics } \\
\cline { 2 - 3 } & Tolerance & VIF \\
\hline X1 & 0.158 & 6.320 \\
\hline X2 & 0.300 & 3.334 \\
\hline X3 & $\mathbf{0 . 1 2 8}$ & 7.795 \\
\hline Y1 & 0.377 & 2.653 \\
\hline
\end{tabular}

Sumber : Data olahan SPSS ver. 18

Dari perhitungan VIF, nilai yang di dapat lebih kecil dari 10 sehingga tidak terdapat masalah multikolinearitas begitu pula nilai TOL mendekati satu sehingga tidak terdapat masalah multikolinearitas.

\section{c. Uji Heterokedastisitas}

Hasil uji Heteroskedastisistas dengan metode Scatterplot menunjukan hasil sebagaimana terdapat pada tabel sebagai berikut: 


\section{Uji Heteroskedastisitas}

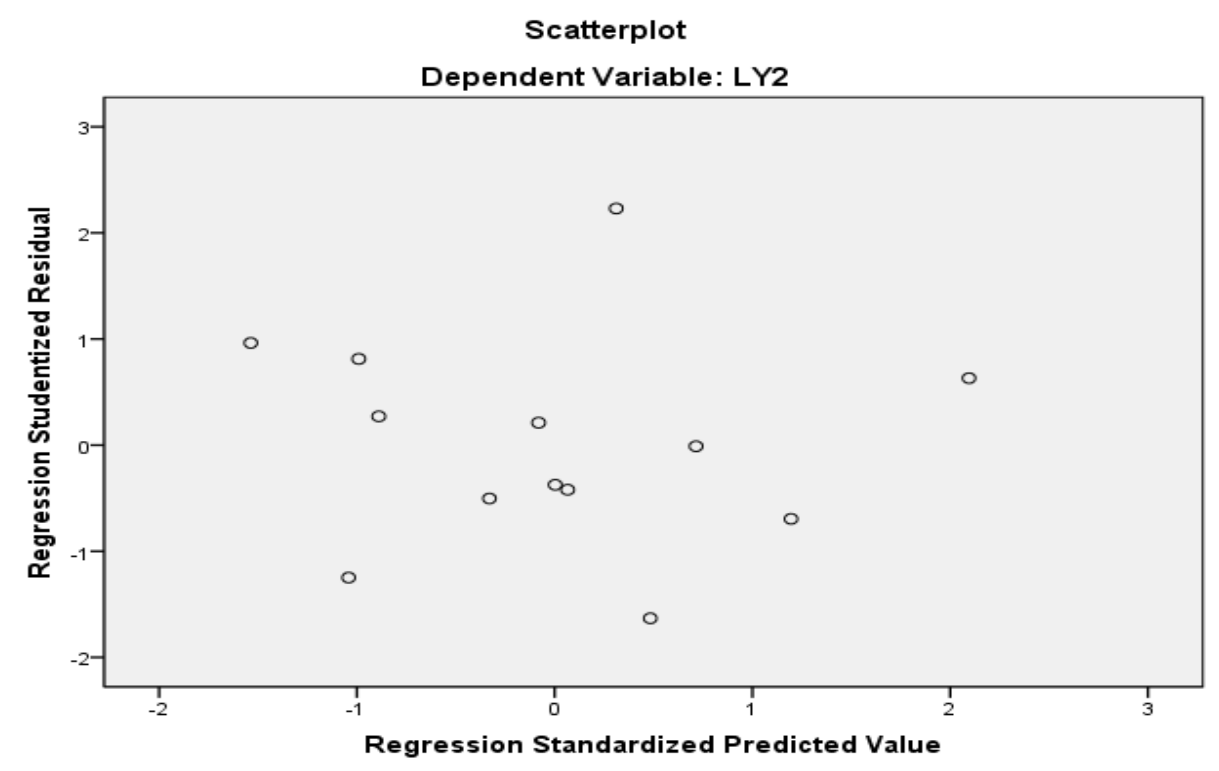

Sumber : Data olahan SPSS ver. 18

Berdasarkan hasil output Scatterplot diatas, terlihat bahwa titik-titik meyebar dan tidak membentuk pola tertentu yang jelas. Sehingga dapat disimpulkan bahwa tidak terjadi masalah heterokedastisitas

\section{d. Uji Autokorelasi}

Hasil uji Autokorelasi dengan metode DW (Durbin Watson) menunjukan hasil sebagaimana terdapat pada tabel sebagai berikut:

\section{Uji Autokorelasi}

Model Summary

\begin{tabular}{|c|c|c|c|c|c|}
\hline Model & $\mathrm{R}$ & R Square & $\begin{array}{l}\text { Adjusted } \mathrm{R} \\
\text { Square }\end{array}$ & $\begin{array}{l}\text { Std. Error of the } \\
\text { Estimate }\end{array}$ & Durbin-Watson \\
\hline 1 & $.729^{\mathrm{a}}$ & .532 & .297 & .036 & 1.775 \\
\hline
\end{tabular}

a. Predictors: (Constant), LY1, LX3, LX2, LX1

b. Dependent Variable: LY2

\section{e. Korelasi Antar Variabel}

Berdasarkan hasil estimasi, diketahui bahwa korelasi antar variabel Investasi (X1), Tenaga Kerja (X2), dan Tingkat Pendidikan (X3) secara individual sebagai berikut. 
Korelasi pada Persamaan Substruktur 1

Correlations

\begin{tabular}{|ll|l|l|l|l|}
\hline & & LX1 & LX2 & LX3 & LY1 \\
\hline LX1 & Pearson Correlation & 1 & .562 & .895 & .247 \\
& Sig. (2-tailed) & & .045 & .000 & .417 \\
& $\mathrm{~N}$ & 13 & 13 & 13 & 13 \\
\hline LX2 & Pearson Correlation & .562 & 1 & .567 & .642 \\
& Sig. (2-tailed) & .045 & & .043 & .018 \\
& $\mathrm{~N}$ & 13 & 13 & 13 & 13 \\
\hline LX3 & Pearson Correlation & .895 & .567 & 1 & .075 \\
& Sig. (2-tailed) & .000 & .043 & & .807 \\
& N & 13 & 13 & 13 & 13 \\
\hline LY1 & Pearson Correlation & .247 & .642 & .075 & 1 \\
& Sig. (2-tailed) & .417 & .018 & .807 & \\
& $\mathrm{~N}$ & 13 & 13 & 13 & 13 \\
\hline
\end{tabular}

*. Correlation is significant at the 0.05 level (2-tailed).

**. Correlation is significant at the 0.01 level (2-tailed).

Sumber : Data olahan SPSS ver. 18

Berdasarkan hasil output diatas, dapat ditarik kesimpulan dengan merujuk pada dasar pengambilan keputusanuji korelasi. Berdasarkan nilai signifikansi dari output diatas diketahui antara investasi (LX1) dengan tenaga kerja (LX2) nilai signifikansi 0,045 < 0,05 yang berarti terdapat korelasi yang signifikan. Kemudian Antara investasi (LX1) dengan tingkat Pendidikan (LX3) nilai signifikansi $0,000<0,05$ yang berarti terdapat korelasi yang signifikan. kemudian antara investasi (LX1) dengan pertumbuhan ekonomi (LY1) nilai signifikansi 0,417 > 0,05 yang berarti tidak terdapat korelasi yang signifikan.

\section{f. Korelasi secara Keseluruhan}

Berdasarkan hasil estimasi, diketahui bahwa korelasi antar variabel Investasi (X1), Tenaga Kerja (X2), Tingkat Pendidikan (X3), Pertumbuhan Ekonomi (Y1) dan Kemiskinan (Y2) secara keseluruhan sebagai berikut. 
Korelasi pada Persamaan Substruktur 1I

\section{Correlations}

\begin{tabular}{|ll|l|l|l|l|l|}
\hline & & LX1 & LX2 & LX3 & LY1 & LY2 \\
\hline LX1 & Pearson Correlation & 1 & .562 & .895 & .247 & -.412 \\
& Sig. (2-tailed) & & .045 & .000 & .417 & .161 \\
& $\mathrm{~N}$ & 13 & 13 & 13 & 13 & 13 \\
\hline LX2 & Pearson Correlation & .562 & 1 & .567 & .642 & -.054 \\
& Sig. (2-tailed) & .045 & & .043 & .018 & .860 \\
& $\mathrm{~N}$ & 13 & 13 & 13 & 13 & 13 \\
\hline LX3 & Pearson Correlation & .895 & .567 & 1 & .075 & -.293 \\
& Sig. (2-tailed) & .000 & .043 & & .807 & .332 \\
& $\mathrm{~N}$ & 13 & 13 & 13 & 13 & 13 \\
\hline LY1 & Pearson Correlation & .247 & .642 & .075 & 1 & .304 \\
& Sig. (2-tailed) & .417 & .018 & .807 & & .312 \\
& $\mathrm{~N}$ & 13 & 13 & 13 & 13 & 13 \\
\hline LY2 & Pearson Correlation & -.412 & -.054 & -.293 & .304 & 1 \\
& Sig. (2-tailed) & .161 & .860 & .332 & .312 & \\
& $\mathrm{~N}$ & 13 & 13 & 13 & 13 & 13 \\
\hline
\end{tabular}

*. Correlation is significant at the 0.05 level (2-tailed).

**. Correlation is significant at the 0.01 level (2-tailed).

Sumber : Data olahan SPSS ver. 18

Berdasarkan hasil output diatas, dapat ditarik kesimpulan dengan merujuk pada dasar pengambilan keputusan uji korelasi. Berdasarkan nilai signifikansi dari output diatas diketahui antara investasi (LX1) dengan tenaga kerja (LX2) nilai signifikansi 0,045 < 0,05 yang berarti terdapat korelasi yang signifikan. Kemudian Antara investasi (LX1) dengan tingkat Pendidikan (LX3) nilai signifikansi $0,000<0,05$ yang berarti terdapat korelasi yang signifikan. kemudian antara investasi (LX1) dengan pertumbuhan ekonomi (LY1) nilai signifikansi 0,417>0,05 yang berarti tidak terdapat korelasi yang signifikan. antara investasi (LX1) dengan kemiskina ( LY2) 0,161 > 0,05 yang berarti tidak terdapat korelasi yang signifikan.

\section{Hasil Estimasi Penelitian}

Berikut hasil regresi untuk mengetahui Pengaruh Investasi, Tenaga Kerja dan Tingkat Pendidikan terhadap Pertumbuhan ekonomi dan Dampaknya Terhadap Kemiskinan di Sulawesi Utara dengan menggunakan metode Path Analysis (analisis jalur). Sesuai dengan pokok permasalahan penelitian ini, maka dapat dilakukan sesuai analisis output SPSS secara berurutan sebagai berikut:

\section{Persamaan Substruktural 1}

Berikut ini merupakan hasil olah data dengan menggunakan SPSS untuk mengetahui pengaruh antara variabel Pertumbuhan Ekonomi (Y1) (variabel dependen) 
dengan Investasi (X1), Tenaga Kerja (X2) dan Tingkat Pendidikan (X3) (variabel independen). Hasil regresi tersebut dapat dilihat pada tabel berikut :

Hasil Regresi Persamaan Substruktur 1

Investasi, Tenaga Kerja dan Tingkat Pendidikan Terhadap Pertumbuhan Ekonomi

\begin{tabular}{|l|l|l|l|}
\hline Variabel & Coefficient & t- statistic & Probabilitas \\
\hline LX1 & 0.313 & 1.445 & 0.182 \\
\hline LX2 & 4.614 & 3.302 & 0.009 \\
\hline LX3 & -2.415 & -2.137 & 0.061 \\
\hline$R^{2}=0.623$ & \multicolumn{3}{|c|}{ F- statistic $=4.960$} \\
\hline
\end{tabular}

Sumber : Data olahan SPSS ver. 18

$Y_{1}=a_{1} X_{1}+a_{2} X_{2}+a_{3} X_{3}-E_{1}$

$$
\mathrm{Y} 1=0.313 \times 1+4.614 \times 2-2.415 \times 3+E_{1}
$$

\section{Uji Parsial (T-Statistik)}

Nilai koefisien Investasi sebesar 0,313 yang berarti bahwa investasi mempunyai pengaruh positif terhadap pertumbuhan ekonomi. Artinya, apabila investasi naik sebesar $1 \%$ maka pertumbuhan ekonomi akan naik sebesar $0.13 \%$ cateris paribus . Hasil sesuai dengan teori yang menyatakan adanya hubungan positif (+) dan berpengaruh secara statistik antara Investasi terhadap pertumbuhan ekonomi pada tingkat keyakinan 90\%. Nilai t hitung sebesar $1.455>\mathrm{t}$ tabel sebesar 1,383. Dengan demikian keputusanya ialah H0 ditolak, dan H1 diterima. Artinya ada hubungan linier antara investasi terhadap pertumbuhan ekonomi.

\section{Uji Simultas (F-Statatistik)}

Nilai F hitung sebesar 4.960 sedangkan F-tabel 2.92. Nilai F table 10\% dengan jumlah variable bebas $(v 2)=2$ dan jumlah sampel 10. Nilai $F$ hitung sebesar $4.960>F$ table sebesar 2.92. Dengan demikian F-statistik lebih besar dari F-tabel yang artinya bahwa Berdasarkan investasi, tenaga kerja, tingkat Pendidikan secara Bersama-sama atau simultan berpengaruh terhadap pertumbuhan ekonomi.

\section{Uji Determinasi $\mathbf{R}^{2}$}

Nilai $\mathrm{R}^{2}$ yang diperoleh sebesar 0.623. artinya, variasi perubahan investasi, tenaga kerja dan tingkat pendidikan mempengaruhi pertumbuhan ekonomi sebesar $62.3 \%$, sedangkan sisanya $(37,7 \%)$ dijelaskan oleh variabel-variabel lain yang tidak dimasukan dalam model. 


\section{Persamaan Substruktur 2}

Berikut ini merupakan hasil olah data dengan menggunakan SPSS untuk mengetahui pengaruh antara variabel Kemiskinan (Y2) (variabel dependen) dengan Investasi (X1), Tingkat Pendidikan (X3) dan Pertumbuhan Ekonomi (Y1) (variabel independen). . Hasil regresi tersebut dapat dilihat pada tabel berikut :

Hasil Regres Persamaan Substuktur 2 Investasi, Tingkat Pendidikan dan Pertumbuhan Ekonomi Terhadap Kemiskinan

\begin{tabular}{|l|l|l|l|}
\hline Variabel & Coefficient & t- statistic & Probabilitas \\
\hline LX1 & -0.226 & -2.323 & 0.049 \\
\hline LX2 & -0.963 & -1.143 & 0.286 \\
\hline LX3 & 0.992 & 1.764 & 0.116 \\
\hline LY1 & 0.304 & 2.251 & 0.054 \\
\hline$R^{2}=0.532$ & & \multicolumn{3}{|c|}{ F- statistic $=2.270$} \\
\hline
\end{tabular}

Sumber : Data olahan SPSS ver. 18

$$
\begin{aligned}
& Y_{2}=b_{1} X_{1}+b 2 X 2+b_{3} X 3+b_{3} Y_{1}+e_{t} \\
& Y_{2}=-0.226 X_{1}-0.963 X_{2}+0.992 X_{3}+0.304 Y_{1}+e_{t}
\end{aligned}
$$

\section{Uji Parsial (T-Statistik)}

Nilai koefisien Investasi sebesar -0.226 yang berarti bahwa investasi mempunyai pengaruh negatif terhadap kemiskinan. Artinya, apabila investasi naik sebesar $1 \%$ maka kemiskinan akan turun sebesar $22,6 \%$ cateris paribus. Hasil ini sesuai dengan teori yang menyatakan adanya hubungan negative (-) dan berpengaruh secara statistik antara Investasi terhadap kemiskinan pada tingkat keyakinan 90\%. Nilai t hitung sebesar - $2.323>\mathrm{t}$ tabel sebesar 1,383. Dengan demikian keputusanya ialah H0 ditolak, dan $\mathrm{H} 1$ diterima. Artinya ada hubungan linier antara investasi terhadap kemiskinan.

\section{Uji Simultas (F-Statatistik)}

Nilai F hitung sebesar 2,270 sedangkan F-tabel 2.92. Nilai F table 10\% dengan jumlah variable bebas $(\mathrm{v} 2)=2$ dan jumlah sampel 10. Nilai $\mathrm{F}$ hitung sebesar 2,506 > F table sebesar 2.92. Dengan demikian F-statistik lebih kecil dari F-tabel yang artinya bahwa Berdasarkan investasi, tenaga kerja, tingkat Pendidikan dan pertumbuhan ekonomi secara Bersama-sama atau simultan tidak berpengaruh terhadap kemiskinan. 


\section{Uji Determinasi $\mathbf{R}^{2}$}

Nilai $\mathrm{R}^{2}$ yang diperoleh sebesar 0.532. artinya, variasi perubahan investasi, tenaga kerja, tingkat Pendidikan dan pertumbuhan ekonomi mempengaruhi kemiskinan sebesar 53.2\%, sedangkan sisanya (46.8\%) dijelaskan oleh variabelvariabel lain yang tidak dimasukan dalam model.

\section{KESIMPULAN DAN SARAN}

\section{Kesimpulam}

1. Investasi memberikan pengaruh yang signifikan terhadap pertumbuhan ekonomi begitu juga dengan tenaga kerja yang memberikan pengaruh yang signifikan terhadap pertumbuhan ekonomi, tingkat Pendidikan juga memberikan pengaruh yang signifikan terhadap pertumbuhan ekonomi.

2. Investasi memberikan pengaruh tidak langsung yang signifikan terhadap kemiskinan melalui pertumbuhan ekonomi di Sulawesi Utara, akan tetapi tenaga kerja secara tidak langsung belum bisa memberikan pengaruh yang signifikan terhadap kemiskinan melalui pertumbuhan ekonomi. Tingkat Pendidikan memberikan pengaruh yang signifikan terhadap kemiskinan.

Pertumbuhan ekonomi memberikan pengaruh yang signifikan terhadap kemiskinan di Sulawesi Utara.

\section{Saran}

Pemerintah diharapkan dapat menciptakan iklim investasi yang kondusif melalui regulasi dan kebijakan yang dapat mendorong masuknya investasi asing lebih besar lagi untuk meningkatkan pertumbuhan ekonomi dalam upaya menurunkan angka kemiskinan. Meskipun secara kuantitas jumlah tenaga kerja memberi kontribusi bagi pertumbuhan ekonomi dan penurunan angka kemiskinan, namun seharusnya disertai dengan upaya peningkatan kualitas tenaga kerja.

\section{DAFTAR PUSTAKA}

Ah Maftuchan 2015, Bergegas Keluar dari Kemiskinan: Berjalan dengan Peta SDGs \& Peta RPJMN. PRAKARSA

Arsyad, Lincolyn (2004), Ekonomi Pembangunan, Bagian Penerbitan, STIE-YKPN, Yogyakarta.

Chamber, Robert. 1987. Pembangunan Desa Mulai Dari Belakang. Jakarta: LP3ES.

Jhingan, M.L. (2010). Ekonomi Pembangunan dan Perencanaan (Alih Bahasa: D. Guritno). Jakarta: Rajawali Pers.

Kuncoro, Mudarajad. 2000. Ekonomi Pembangunan: Teori, Masalah dan kebijakan, UPP AMP YKPN: Yogyakarta 
Sumedi dan Supadi. 2004. Kemiskinan di Indonesia: Suatu Fenomena Ekonomi.Icaserd Working Paper No. 21. Pusat Penelitian dan Pengembangan Sosial Ekonomi Pertanian, Badan Penelitian dan Pengembangan Pertanian,Departemen Pertanian. Bogor.

Mankiw, N. Gregory. 2003. Pengantar Ekonomi, Ed.2, Jilid 1, Jakarta: Erlangga.

Todaro, Michael P., dan Smith, Stephen C. (2006). Pembangunan Ekonomi/ Edisi Kesembilan, Jilid 1 (Alih Bahasa: Haris Munandar dan Puji A.L.). Jakarta: Penerbit Erlangga. 